\title{
The Effects of Letrozole in Transfer of Maternal Immunity against Lactococcosis to Eggs and Larvae in Rainbow Trout (Oncorhynchus mykiss, Walbaum)
}

\author{
Paria Akbary ${ }^{1}$, Ali Reza Mirvaghefi ${ }^{*}$, Mostafa Akhlaghi², Bagher Majazi Amiri ${ }^{1}$, \\ Mohammad Saeid Fereidouni' ${ }^{2}$ \\ ${ }^{1}$ Department of Fisheries and Environmental Sciences, Faculty of Natural Resources, College of Agriculture \& \\ Natural Resources, University of Tehran, Karaj, Iran \\ ${ }^{2}$ Department of Aquatic Animal Health Unit, School of Veterinary Medicine, Shiraz University, Shiraz, Iran \\ Email:
}

Received 22 January 2015; accepted 9 February 2015; published 12 February 2015

Copyright (C) 2015 by authors and Scientific Research Publishing Inc.

This work is licensed under the Creative Commons Attribution International License (CC BY). http://creativecommons.org/licenses/by/4.0/ c) (i) Open Access

\section{Abstract}

This study evaluated transfer of maternal lysozyme and immunoglobulin (IgM) against Lactococcus garviea, the causative agent of lactococcosis to eggs and larvae in rainbow trout. Changes in circulating lysozyme and IgM during development of eggs and larvae were measured by a method based on the ability of lysozyme to lyse the bacterium Micrococcus lysodeikticus and enzymelinked immunosorbent assay (ELISA) respectively. For doing this, twelve broodstocks were injected weekly with $2.5 \mathrm{mg} \cdot \mathrm{kg}^{-1}$ letrozole (an endocrine disrupter component) two months before spawning season and vaccinated intraperitoneally (i.p) with a bacterin (inactivated L. garviae) one month before spawning. Twelve broodstocks for vaccination and twelve female rainbow trouts as control group were also immiunised (i.p) with the bacterin and injected (i.p) with PBS respectively. Results showed that at day 8 after hatching, lysozyme and IgM levels during pre-larval stages decreased gradually, as yolks were absorbed. Lysozyme and IgM levels were significantly higher in the letrozole injected immiunised parents 30 days after immunisation as well as their larvae compared to the control group $(p<0.05)$. These results showed the lysozyme and IgM detected from day 0 to day 8 derived from maternal fish while the lysozyme and IgM detected from day 10 onward are neo-synthesized lysozyme and IgM. The present study indicated the role of the injection of letrozole (two months before spawning) and parent immunisation with a bacterin (inactivated $L$. garviae) (one month before spawning) in maternal transfer of lysozyme and IgM levels to eggs and larvae.

\footnotetext{
${ }^{*}$ Corresponding author.
}

How to cite this paper: Akbary, P., et al. (2015) The Effects of Letrozole in Transfer of Maternal Immunity against Lactococcosis to Eggs and Larvae in Rainbow Trout (Oncorhynchus mykiss, Walbaum). Food and Nutrition Sciences, 6, $254-264$. http://dx.doi.org/10.4236/fns.2015.62026 


\section{Keywords}

\section{Maternal Transfer, Immunoglobulin, Lysozyme, Lactococcosis, Rainbow Trout}

\section{Introduction}

Lactococcosis is a bacterial disease caused by Lactococcus garvieae that occurs in freshwater as well as seawater and has been a source of major economic losses since the early seventies for rainbow trout (Oncorhynchus mykiss) and marine fish industries in Asia (rainbow trout and yellowtail, Seriola quingueradiata) as well as in the United State of America and South Africa [1].

Fish larvae do not have the ability to develop specific immunity during the early stages of development [2] [3]. Fresh water species like rainbow trout and channel catfish show the first appearance of surface IgM about 1 week after hatching [4]. Commonly, fish larvae have reached about 20 - $30 \mathrm{~mm}$ in length when IgM is first expressed. In this respect, it has been speculated that the relatively appearance of authologous humoral IgM may be, to some extent, compensated by maternally derived immunoglobulins [5] [6]. Maternal IgM has been demonstrated in the eggs and embryos of several fish species like plaice [6] [7], Carp [8], sea bass [9] [10]. And salmon [11] but not in cod [12] and may be involved in the early defence against pathogens in eggs containing developing embryo and larvae, since the relatively late appearance of authologous humoral IgM [5] [6].

Lysozyme is an important innate defence parameter and is widely distributed in invertebrates and vertebrates. The enzyme has been detected in oocytes, fertilized eggs and larval stages of fish species like coho salmon, sea bass and tilapia [6]. The presence of humoral non-specific factors such as lysozyme has been reported in the eggs of different teleost species [13] [14].

During the last decade, a number of studies have shown that in addition to their classically described reproductive functions, estrogens and androgens also regulate the immune system in teleost [15]. The reproductive immune interactions studied in fishes indicate that sexual maturation (i.e., gonadal maturity and reproductive activities) can potentially affect both the innate and adaptive immune responses [16] [17]. In fish, the reproductive cycle is marked by seasonal variation in plasma sex steroids and by changes in immune parameters which render them more sensitive to the presence of pathogens [18]. Furthermore, immune biomarkers may prove useful for the identification of contamination in the wild [17]. In some studies, it is shown that the rise of 17- $\beta$-estradiol during the spawning season affects the lymphocyte proliferation and IgM level, and antibody_producing cells in several fish species like Oncorhynchus mykiss, Salmo trutta, Chinook salmon, Oncorhynchus tshawytscha, gold fish, Carassius auratus [18]-[21]. Letrozole (CGS 20264), with commonly used brand name Femara, is a non-steroidal trizole derivation and one of the most potent aromatase inhibitors yet developed as endocrine disrupter component (EDC). Letrozole is capable of inhibiting aromatase $98 \%$ - 99\% and reducing serum concentrations of estrone and $E_{2}$ beyond the limit of detection in patients [22]. Our results in a recent study showed that, $\mathrm{E}_{2}$ levels were significantly decreased in all fish injected by letrozole in comparison to control group from 6 to $96 \mathrm{~h}$ after injection with AI [23].

Little information is available on the immune response and transfer of maternal immunity of rainbow trout larvae as well as to define the most effective immunisation protocol for particular species such as rainbow trout. The fate of maternally derived IgM in yolk is still unknown in species, although it is probably transferred from the larval yolk sac into their circulation. This study was conducted in order to obtain further evidence on the transfer of maternal immune parameters (IgM, lysozyme) of rainbow trout to their offspring against lacotococcosis along with effects of letrozole on lysozyme and IgM levels after female immunisation of rainbow trout.

\section{Materials and Methods}

\subsection{Letrozole}

The non-steroidal aromatase inhibitor letrozole (CGS 20267) [1H]-4-androstron-3,17-dione, obtained as a gift from Iran hormone venture pharmaceutical technology development Co., Ltd., Iran was dissolved in the vehicle ethanol [24]. Stock solutions which contained $2.5 \mathrm{mg}$ of AI ml${ }^{-1}$ were prepared. 


\subsection{Bacteria and Bacterin (Vaccine) Preparation}

Lactococcus garvieae (EU727199) was isolated from diseased fish showing signs of lactococcosis which were collected from rainbow trout farms in Fars province (obtained from the Shiraz University, Shiraz, Iran). This strain was selected on the basis of its antigenic characteristics that were determined in a previous work [25]. The strain was routinely grown onto Columbia sheep blood agar (Oxid, Madrid, Spain) plates at $25^{\circ} \mathrm{C}$ for $24-48 \mathrm{~h}$. Stock cultures were maintained frozen at $-80^{\circ} \mathrm{C}$ in tryptone soy broth (Difco, Madrid, Spain) with $15 \%$ glycerol.

A formaline-killed vaccine was prepared as previously described [26] [27]. The selected strain of L. garvieae was grown in Trypticase Soy Broth (TSB, Difco) for $48 \mathrm{~h}$. Bacterial cells were killed by addition of formalin to achieve a final concentration of $0.3 \%$ and incubated for $3 \mathrm{~h}$ at $25^{\circ} \mathrm{C}$ and then $4{ }^{\circ} \mathrm{C}$ overnight. Bacterial cells were collected by centrifugation at $6500 \times \mathrm{g}$ for $30 \mathrm{~min}$ at $4^{\circ} \mathrm{C}$ and washed three times with phosphate buffered saline (PBS: $\mathrm{pH} 7.4$ ) and then were resuspended in PBS at a final concentration of $1.2 \times 10^{8} \mathrm{cfu} \cdot \mathrm{ml}^{-1}$.

\subsection{Fish}

Thirty six adult rainbow trout (Oncorhynchus mykiss) females were obtained in mid-September 2011 from Dalkhan rainbow trout hatchery farm, Sepidan, west of Shiraz, Iran and held outdoor in a $10 \mathrm{~m}^{2}$ concrete pond in a flow-through water system. The fish were kept in well-aerated water at $15.8^{\circ} \mathrm{C} \pm 0.5^{\circ} \mathrm{C}$, dissolved oxygen $5.5 \pm 0.1 \mathrm{ppm}$ and $\mathrm{pH} 7.8 \pm 0.18$. Fish were initially weighted ( $854 \pm 0.1 \mathrm{~g})$ under anesthesia (150 ppm clove oil). After 7 days of acclimation to the condition, they were randomly divided in three groups and each group was kept in a $2 \mathrm{~m}^{2}$ concrete pond with a water depth of $50 \mathrm{~cm}$ in the same flow through water system. During the experiment, the fish were fed with commercial salmon food (Beyza 121 Feed Mill (BFM) Co., Ltd., Iran).

\subsection{Letrozole Injection of Brood Fish}

These procedures were carried out at least 3 days after females had been transferred to $2 \mathrm{~m}^{2}$ concrete ponds. In mid-August 2011, twelve fish were injected itraperitonially (i.p) weekly with $2.5 \mathrm{mg} \cdot \mathrm{kg}^{-1}$ letrozole at the base of the right ventral fin using individual $4 \mathrm{ml}$ syringes fitted with an 18.5 gauge needle. Twenty four fish were injected with the vehicle ethanol only $\left(1.0 \mathrm{ml} \cdot \mathrm{kg}^{-1}\right.$ body weight).

\subsection{Vaccination of Brood Fish}

In mid-September, letrozole injected parents, were immiunised with $1.0 \mathrm{ml}$ of formalin (3\%) inactivated Lactococcus garvieae $\left(10^{9}\right.$ cells $\left.\mathrm{ml}^{-1}\right)(\mathrm{n}=12)$. Also twenty four fish injected only with ethanol were divided in two groups. Control group $(\mathrm{n}=12)$ was immiunised (i.p) with $1.0 \mathrm{ml}$ sterile PBS (phosphate-buffered saline $0.1 \mathrm{M}$, $\mathrm{pH}$ 7.2) and group immiunised with $1.0 \mathrm{ml}$ of formalin (3\%) inactivated Lactococcus garvieae $\left(10^{9} \mathrm{cells}^{\mathrm{s}} \cdot \mathrm{ml}^{-1}\right)$. Before any handling procedure, fish were anaesthetized a solution of freshly powdered clove oil with concentration of $150 \mathrm{ppm}$.

\subsection{Serum Sampling}

Blood was collected from the caudal vein of fish prior to immunisation and every ten day post-injection, random serum samples were obtained from six fish per raceway pond (non-lethal bleeding) of the immunised and control fish, and allowed to clot at room temperature for $1-2 \mathrm{~h}$ and then at $4^{\circ} \mathrm{C}$ overnight. Sera were collected and stored at $-20^{\circ} \mathrm{C}$.

\subsection{Eggs and Larvae}

Eggs (in $5 \mathrm{ml}$ container) were collected thirty days after the last injections. Then after, egg samples were collected every fifth day after spawning and stored at $-20^{\circ} \mathrm{C}$ for further use. Larvae (two groups) were collected every 2 nd day until day 10 post-hatching and then every 4 th day.

\subsection{Homogenates of Eggs and Larvae}

Eggs and larvae were washed two times with sterile PBS, pH 7.2, homogenized with 1 volume of PBS and cen- 
trifuged at $3000 \mathrm{~g}$ for $10 \mathrm{~min}$ at $4^{\circ} \mathrm{C}$. The supernatants were collected, centrifuged once at $3000 \mathrm{~g}$ for $5 \mathrm{~min}$ and stored at $-20^{\circ} \mathrm{C}$.

\subsection{Weight of Larvae}

Samples from the different larval stages were collected, weighted, rinsed with distilled water, and their wet body weight measured and recorded. From day 0 to 18, groups of 50 larvae were used due to smaller size. After day 18, 10 larvae per group were sampled.

\subsection{Immunological Assays}

\subsubsection{Lysozyme}

The lysozyme activity of samples (serum, eggs or larval homogenates) was measured using a method based on the ability of lysozyme to lyse the bacterium Micrococcus lysodeikticus [28]. In a 96-well microplate, $250 \mu \mathrm{l}$ of samples (serum, eggs or larval homogenates) in four twofold serial dilutions in PBS (0.05 M, pH 7.2) were mixed with $250 \mu \mathrm{l}$ of $0.7 \mathrm{mg} \cdot \mathrm{ml}^{-1}$ suspension of Micrococcus lysodeikticus (Sigma) in phosphate buffer (175 $\mathrm{ml}$ ). The microplate was incubated at $24^{\circ} \mathrm{C}$ and O.D. was read at $450 \mathrm{~nm}$ at 15 and $30 \mathrm{~min}$. For a positive and a control, serum was replaced by hen egg white lysozyme (serial dilutions starting at $1.6 \mu \mathrm{g} \cdot \mathrm{ml}^{-1}$ ) and buffer respectively. A unit of lysozyme activity was defined as the amount of serum causing a decrease in the O.D. reading of $0.001 \mathrm{~min}$.

\subsubsection{Total IgM}

The serum samples (serum, eggs or larval homogenates) from weekly letrozole injected immunised, only immunised and non-immunised and extracts from eggs and larvae originating from all groups were assessed with ELISA to measure total IgM by the method of Hanif et al. [3] with slight modification as follows: 3 washes with PBS containing 0.05\% Tween 20 (PBS-Tween) were performed between steps. Each well of microplate (Falcon, USA), which was coated with $50 \mu \mathrm{l}$ of rabbit anti-rainbow trout IgM $(6.6 \mu \mathrm{g} / \mathrm{ml})$ (Sigma, St. Louis, USA), was incubated for $2 \mathrm{~h}$ at $37^{\circ} \mathrm{C}$. After washing, $50 \mu \mathrm{l}$ of serum, eggs or larval homogenates serially diluted standards from 800 to $3.2 \mathrm{ng} / \mathrm{ml}$ and were added to the wells, and the plate was incubated overnight at $4^{\circ} \mathrm{C}$. After washing, $50 \mu \mathrm{l}$ of goat anti-trout antibody which was conjugated with horse radish peroxidase (Sigma, St. Louis, MO), and diluted in PBS-Tween, was added to the plate, and incubated for $2 \mathrm{~h}$ at $37^{\circ} \mathrm{C}$. After washing, peroxidase activity was measured by adding $50 \mu \mathrm{l}$ of substrate solution which contained o-phenylenediamine dihydrochloride ( $1 \mathrm{mg} / \mathrm{ml}$, BRL, USA) and $0.04 \% \mathrm{H}_{2} \mathrm{O}_{2}$ in $0.1 \mathrm{M}$ citrate/0.2 M phosphate buffer (pH 5.5). After incubation for $30 \mathrm{~min}$ at room temperature, the enzyme-substrate reaction was stopped by adding $25 \mu \mathrm{l}$ of $2 \mathrm{M} \mathrm{H}_{2} \mathrm{SO}_{4}$ to each well and the color change was measured spectrophotometrically at a wavelength of $450 \mathrm{~nm} \pm 2 \mathrm{~nm}$. All samples were placed in triplicate on the plates and the mean and standard deviation (S.D.) were calculated for each sample IgM concentration. Data were expressed either as $\mathrm{mg} \cdot \mathrm{ml}^{-1}$ for serum and $\mu \mathrm{g} \cdot \mathrm{g}^{-1}$ of wet body weight in eggs or larvae.

\subsection{Statistical Analysis}

Data were evaluated using one-way analysis of variance (ANOVA). Groups were considered to be significantly different if $P<0.05$. When a significant $F$ value was obtained for ANOVA the differences between all groups were tested by using Duncan multiple comparisons test. All statistics were performed using SPSS for windows version 16.

\section{Results}

\subsection{Larval Growth}

The wet weights (mg) of larvae were recorded in three groups from days 0 - 58. A difference in body weight increase was observed in larvae from immunized and non-immunized brood fish as compared to larvae from weekly letrozole injected immunised parents (Figure 1), especially from day 34. But this difference in growth and wet body weight of larvae from three groups was non-significant. 


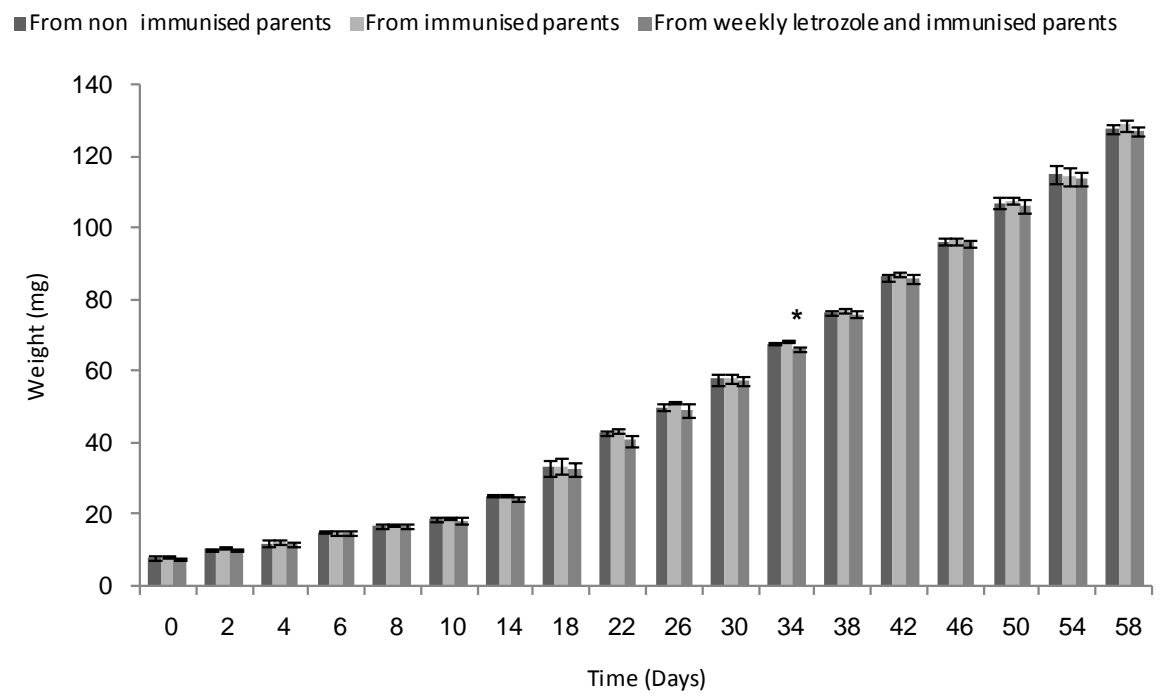

Figure 1. Changes in wet body weight with development of rainbow trout larvae derived from non immunised, letrozole injected immunised and immunised rainbow trout broodstocks. Each data point represents the mean ( \pm S.E.) of triplicates.

\subsection{Immunological Assays}

\subsubsection{Lysozyme}

The lysozyme activity $\left(\mu \mathrm{g} \cdot \mathrm{ml}^{-1}\right)$ in sera of the injected weekly with letrozole and immunised parents was higher $\left(294.31 \pm 2.02\right.$ units $\left.\cdot \mathrm{ml}^{-1}\right)$ than the immunised $\left(287.26 \pm 1.91\right.$ units $\left.\cdot \mathrm{ml}^{-1}\right)$ and the non-immunised in sera of bloodstocks at day 30 (Figure 2(a)). The difference was significant among the groups ( $p<0.05$ ). Duncan multiple comparison was performed for comparison between groups (Figure 2(a)). Egg extracts from the injected with letrozole and immunised group expressed (Figure 2(b)) significantly $(\mathrm{p}<0.05)$ higher lysozyme activity as compared to the non-immunised and the non-immunised group at day 30. In larval extracts, the lysozyme activity was higher in larvae from injected with letrozole and immunised parents as compared to larvae from the immunised and the non-immunised parents during development (Figure 2(c)). From day 0 to day 8 after hatching, lysozyme levels in larvae extracts originated from weekly injected letrozole and immunised parents and from the only immunised parents were more than larvae extracts originated from the non-immunised parents ( $\mathrm{p}$ $<0.05$ ). From 10 to day 58, an increase was observed in lysozyme activity of larval extracts from both immunised groups and larval extracts from non-immunised brood fish (Figure 2(c)).

\subsubsection{Total Immunoglobulin (IgM)}

Total immunoglobulin levels in the sera of the injected weekly with letrozole and immunised broodstocks (11.06 $\left.\pm 0.03 \mathrm{mg} \cdot \mathrm{ml}^{-1}\right)$ was higher than the only immunised $\left(10.47 \pm 0.26 \mathrm{mg} \cdot \mathrm{ml}^{-1}\right)$ and the non-immune $(7.91 \pm 0.06$ $\mathrm{mg} \cdot \mathrm{ml}^{-1}$ ) beoodstock sera at day 30 (Figure 3(a)). The difference was significant among the groups $(\mathrm{p}<0.05)$. Egg and larval extracts from the injected weekly with letrozole and immunised group expressed higher IgM levels than the only immunised and the non-immunised groups (Figure 3(b) and Figure 3(c)). But the difference was not significant between the small amounts of IgM were detected in the immunised and non-immunised eggs. While the difference between immunized and non-immmunised eggs seems to be significant in Figure 3(b). In larvae, this amount gradually decreased from day 0 to day 8 . The IgM was not detectable in non-immunised larvae from day 2 to 8 while small amounts of IgM were present in the larvae from immunised groups at the same days. Then this IgM level gradually increased in both groups from day 10 until the end of the experiment at day 58 (Figure 3(c)).

\section{Discussion}

The aquaculture industry is recently facing a serious setback due to infectious [29] diseases leading to severe economic loss [30] [31]. Although mortalities have been reported in all stages of life, maximum mortalities in all 


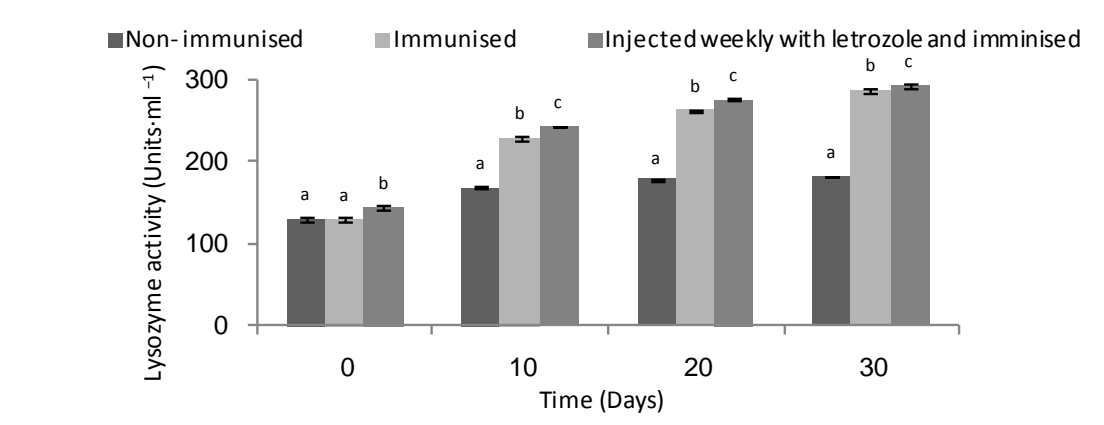

(a)

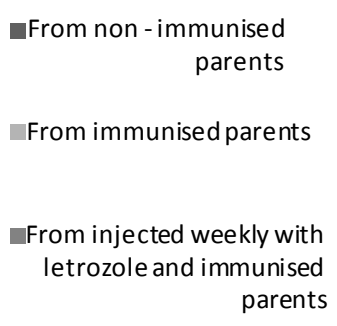

—From non-immunised parents

_- From immunised parents

- From injected weekly with letrozole and immunosed parents

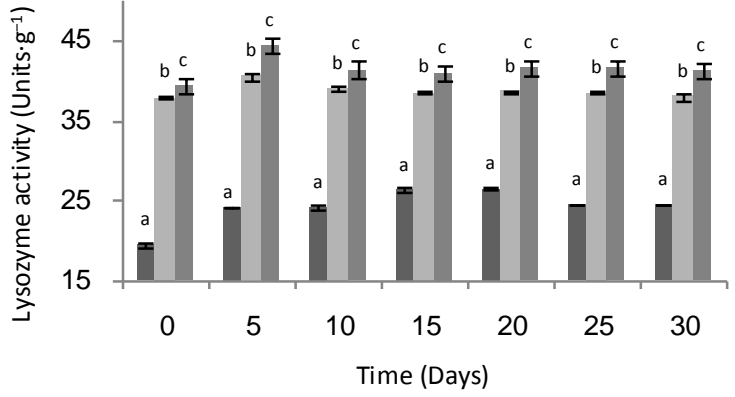

(b)

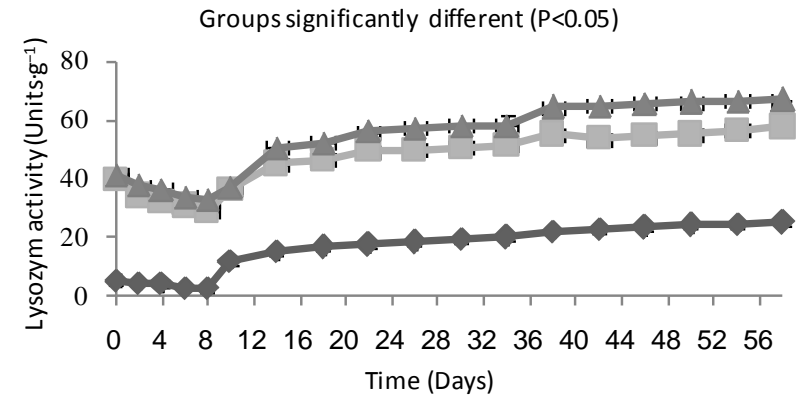

(c)

Figure 2. Total lysozyme level changes in after injection weekly with letrozole and immunisation of the rainbow trout broodstock. (a) Broodstock serum (units $\cdot \mathrm{ml}^{-1}$ ); (b) Eggs extracts (units $\cdot \mathrm{g}^{-1}$ wet weight) after spawning; (c) Larval extracts (units $\cdot \mathrm{g}^{-1}$ wet weight) during development. Each data point represents the mean $( \pm$ S.E.) of triplicates.

the cultivated fish species have been reported at larval stages. Due to lack of immune competence at the early stages [29], an alternate method was evaluated for enhancing the resistance for more availability of healthy fish seed by immunisation. In a study in 2002 in Iran from 235 cases of streptococcosis among rainbow trout collected from farms of Fars province, streptococci were isolated from 199 cases. These isolates were biochemically allocated to Streptococcus iniae and Lactococcus garvieae [32]. Also L. garvieae outbreaks in farmed rainbow trout are described from different parts of Iran [33].

The total immunoglobulin level in the sera of the injected with letrozole and immunised broodstocks $(11.06 \pm$ $\left.0.03 \mathrm{mg} \cdot \mathrm{ml}^{-1}\right)$ was higher the immunised $\left(10.47 \pm 0.29 \mathrm{mg} \cdot \mathrm{ml}^{-1}\right)$ and the non-immunised $\left(7.91 \pm 0.23 \mathrm{mg} \cdot \mathrm{ml}^{-1}\right)$ broodstocks (Figure 3). This is in agreement with observation in rainbow trout [34], gilthead seabream [35]. Sex hormones are usually elevated during spawning season of fishes and the rise of sex hormones can severely affect the immunity of fishes [19] [36]. The rise of estradiol-17- $\beta$ is reported to affect IgM level, and antibody-producing cells in several fish species like Oncorhynchus mykiss, Salmo trutta, Chinook salmon, Oncorhynchus tshawytscha, gold fish, Carassius auratus [18]-[21]. For example in O mykiss [34] [37] and gilthead seabream [35], shown that the rise of sex hormones can suppress the plasma IgM and IgM secreting cells during spawning period leading to immunosuppressive condition. Due to, elevation of sex steroids can make fish more vulnerable 

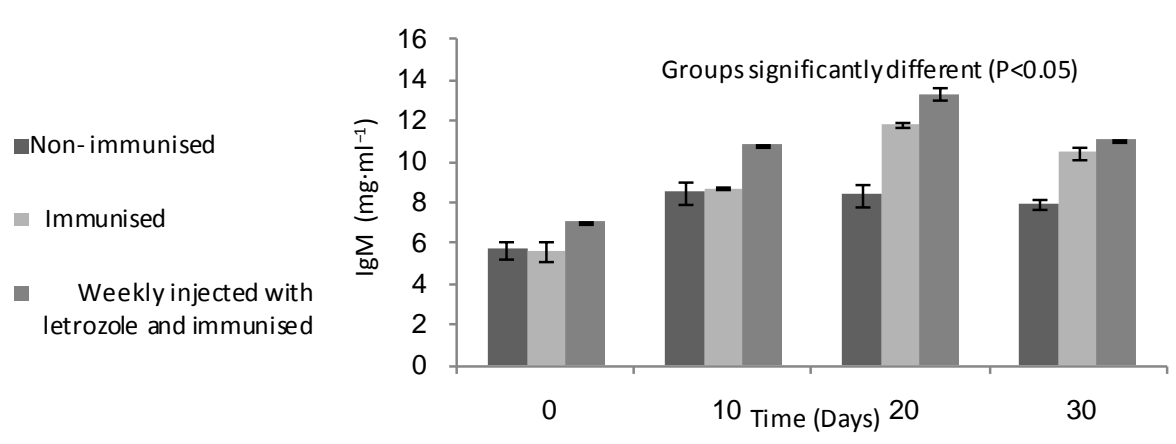

(a)
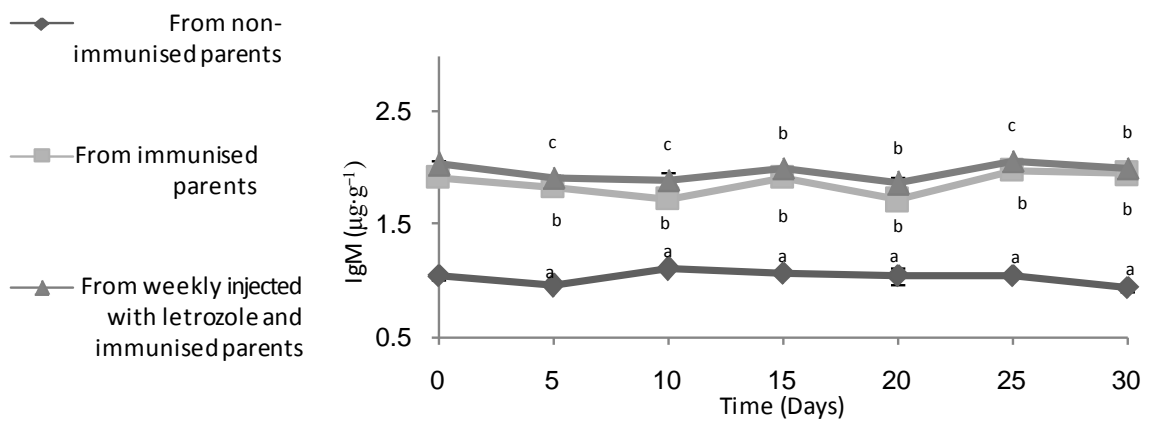

(b)
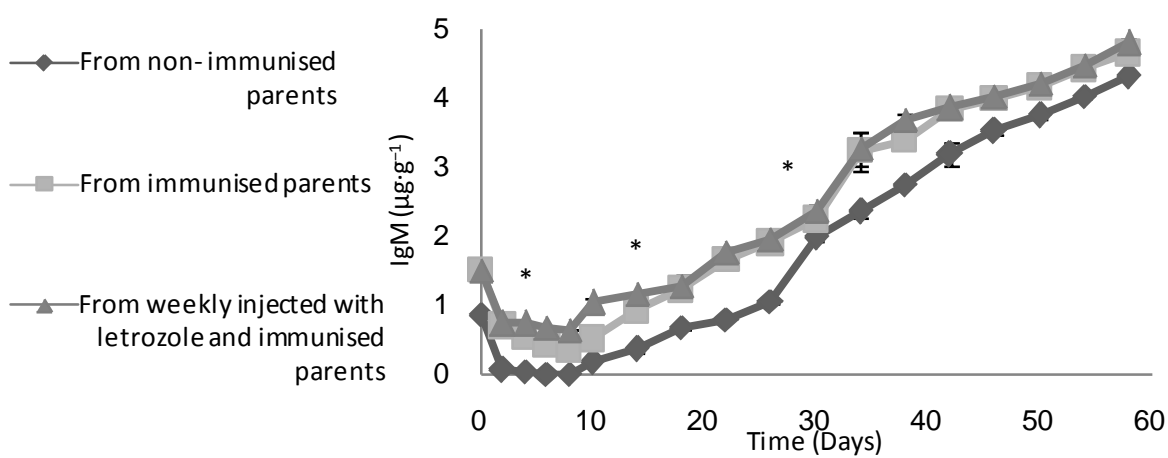

(c)

Figure 3. Total IgM level changes after injection weekly with letrozole and immunisation of the rainbow trout broodstock. (a) Broodstock serum $\left(\mathrm{mg} \cdot \mathrm{ml}^{-1}\right)$; (b) Eggs extracts $\left(\mu \mathrm{g} \cdot \mathrm{g}^{-1}\right.$ wet weight) after spawning; (c) Larval extracts ( $\mu \mathrm{g} \cdot \mathrm{g}^{-1}$ wet body weight) during development. Each data point represents the mean $( \pm$ S.E.) of triplicates. Similar values among the groups are identified by the same superscript letter $(\mathrm{p}>0.05)$.

to several microbial infections during the spawning season and subsequent mortality following the spawning phase. We used the endocrine disrupter component (EDC) letrozole for rising lysozyme and IgM levels in immunised females.

The significant rise in lysozyme (Figure 2) IgM (Figure 3) levels of the broodstocks injected with letrozole and immunised and only immunised, one month before breeding was observed .A set of genes related to innate immunity in vertebrates, including chemotoxin, poly saccharide-binding protein1, and antimicrobial peptide hepcidin were down-regulated after exposure to estrogen [38] [39]. In the present study, the significant rise in antibody level adult females injected weekly with letrozole and immunised also females only immunised 1 month before breeding was observed and that was successfully transferred to offspring. However, only a low level of antibody was found to be transferred from mother to larvae. Sin et al. [40] reported significant antibody against Ichthtyophinus multifilis in Oreochromis aureus by immunising 1 month prior to spawning and also re- 
ported successful transfer of antibody from mother to offspring. The successful transfer of immunoglobulin antibody from mother to offspring has also earlier been reported in many fish species including plaice [41], tilapia [42]-[44], red sea bream [45] and sea bream [46]. In the present study, the high levels of circulating antibodies detected against $L$. garvieae confirmed the immune response of the parents. This study investigates the vertical transmission of immunity (lysozyme and IgM parameters) in eggs and larvae.

Lysozyme is a bactericidal enzyme, involved in hydrolysis of the $\beta$ - $(1,4)$ linked glycoside bonds of bacterial cell wall peptidoglycans. Lysozyme has also been detected in oocytes, fertilized eggs and larval stages of several species, for examples eggs of coho salmon and other salmonids [6]. This study demonstrated that the lysozyme activity in the sera from injected weekly with letrozole and immunised parents were much higher than the only immunised and non-immunised group sera. In addition, egg and larval extracts from the injected weekly with letrozole and vaccinated group showed higher activities in comparison to the only vaccinated and the non-vaccinated parents (Figure 2). Lysozyme activity detected in the eggs was probably derived from the parents, and the activity level decreased from hatching to larval stage from 2 to day 8 in three groups, which may correspond to the yolk absorption and a natural protein catabolism during this period. At day 8 after hatching, larval extracts from the injected weekly with letrozole and immunised group and the only immunised group expressed more lysozyme activity than the non-immunised group and the same trend of higher lysozyme activity was observed in larvae from all of the groups until day 58 (Figure 2(c)). This increase during early stages may be due to the transfer of maternal immunity in larvae from immunised parents as it is supported by the presence of higher lysozyme activity in eggs from immunised parents. The present results are comparable with other studies in some fish species. High levels of lysozyme have been found in sea bream [46]. The lysozyme present in sea bream eggs was bactericidal to photobacterium sp. Also there are several reports of lysozyme isolated from fish serum and ova, being bactericidal even for important fish pathogens like A.salmoncida and A. hydrophila [15].

Total IgM levels of samples (serum, egg and larval extracts) originating from the only immunised parents and weekly injected with letrozole and immunised parents were higher in comparison to similar activities from samples from the non-immunised parents (Figure 3). The IgM concentration of rainbow trout serum was comparable to the IgM level seen Atlantic salmon (Salmo salar L.) [11] and sea bream (Sparus aurata) [3]. The measurement of egg IgM concentration in Oncorhynchus mykiss gave results comparable to those found in other teleost fish species, such as sea bream [47] and Sparus auratus [46]. Data available from other teleosts have indicated that maternal supply specific IgM is very low, gradually declining with time, and consequently of limited duration [48] [49]. In sea bass, for example, maternal IgM is deposited in the ovary during vitellogenesis and reaches maximum concentration during ovulation. At hatching this level had been reduced about 100-fold and 5 d.p.h. No maternal IgM was detected in sea bass larvae [10] [50]. A similar situation has been demonstrated in tilapia [51] and Atlantic salmon [11]. In this study, the IgM level detected in the eggs probably derived from the mother, and the activity level decreased from hatching to larval stage day 8 in three groups, which may correspond to the yolk absorption and a natural protein catabolism during this period (Figure 3(c)). At days 0 and 8 small amounts of immunoglobulin were detectable in larval extracts from the immunised group and injected weekly with letrozole and immunised group, whereas no IgM was found in larval extracts from the nonimmunised group. Furthermore, higher IgM levels were observed in larvae from injected weekly with letrozole and immunised parents as compared to the larvae extracts from the non-immunised parents until day 58. There was no significant difference between IgM levels in larval extarcts from immunised parents and injected weekly with letrozole and immunised parents ( $p>0.05)$. The low levels of IgM in eggs and larvae indicate that there is no specific transport mechanism for immunoglobulin from the mother [52]. Possibly the primary role of maternal antibodies is to protect the eggs against vertical transfer of certain pathogens or maternal IgM may aid phagocytosis or the activation of complement pathways in early development stages; IgM may even function simply as a nutritional yolk protein [6] [53]. The present ELISA results come close to those reported in other fish species such as tilapia [51], chum salmon [53] and sea bream [46].

The wet body weight of the only immunised group larvae was higher than the injected weekly letrozole and immunised group and the non-immunised group larvae (Figure 1). This trend (although statically non-significant) would be an important outcome for the growth characteristics of larvae if an attribution to the immunisation of parents can be established.

Finally, the injection of letrozole and vaccination of brood fish through bacteria (L. garvieae) has significantly enhanced the non-specific factor (lysozyme) in comparison to other two groups ( $p<0.05$ ), in the egg and larval extracts. But the IgM level in egg and larval extracts from immunised and injected weekly with letrozole and 
immunised parents had not significantly different $(\mathrm{p}>0.05)$. Further studies are ongoing to elucidate the modulation of different non-specific factors following specific immunisation. Therefore, the present investigation revealed the transfer of maternal antibodies from mother to egg and their existence at different stages of larval growth. Hence, using non-steroidal compounds and immunised broodstocks of rainbow trout prior to breeding can be recommended for better health management and to overcome the challenges in vaccinating large number of larvae at a time.

\section{References}

[1] Vendrell, D., Balcázar, J.L., Ruiz-Zarzuela, I., Blas, I.D., Gironés, O. and Mùzquiz, J.L. (2006) Lactococcus garvieae in Fish: A Review. Comparative Immunology Microbiology and Infectious Disease, 29, 177-198. http://dx.doi.org/10.1016/j.cimid.2006.06.003

[2] Ellis, A.E. (1988) Ontogeny of the Immune System in Teleost Fish. In: Ellis, A.E., Ed., Fish Vaccination, Academic Press, London, 20-31.

[3] Hanif, A., Bakopoulos, V. and Dimitriadis, G.J. (2004) Maternal Transfer of Humoral Specific and Non-Specific Immune Parameters to Sea Bream (Sparus auratus) Larvae. Fish Shellfish Immunology, 17, 411-435. http://dx.doi.org/10.1016/j.fsi.2004.04.013

[4] Petrie-Hanson, L. and Ainsworth, A.J. (2001) Ontogeny of Channel Catfish Lymphoid Organs. Veterinary Immunology and Immunopathology, 81, 113-127. http://dx.doi.org/10.1016/S0165-2427(01)00331-2

[5] Zhang, S., Wang, Z. and Wang, H. (2013) Maternal Immunity in Fish. Development and Comparative Immunology, 39, 72-78. http://dx.doi.org/10.1016/j.dci.2012.02.009

[6] Magnadottir, B., Lange, S., Gudmundsdottir, S., Bøgwald, J. and Dalmo, R.A. (2005) Ontogeny of Humoral Immune Parameters in Fish. Fish and Shellfish Immonology, 19, 429-439. http://dx.doi.org/10.1016/j.fsi.2005.03.010

[7] Bly, J.E., Grimm, A.S. and Morris, I.G. (1986) Transfer of Passive Immunity from Mother to Young in a Teleost Fish: Haemagglutinating Activity in the Serum and Eggs of Plaice, Pleuronectes platessa L. Comparative Biochemistry and Physiology Part A, 84, 309-313. http://dx.doi.org/10.1016/0300-9629(86)90620-1

[8] Suzuki, Y., Orito, M., Furukawa, K. and Aida, K. (1994) Existence of Low Molecular Weight Immunoglobulin-M in Carp Eggs. Fisheries Science, 60, 152-169.

[9] Breuil, G., Vassiloglou, B., Pepin, J.F. and Romestand, B. (1997) Ontogeny of IgM-Bearing Cells and Changes in the Immunoglobulin M-Like Protein Level (IgM) during Larval Stages in Sea Bass (Dicentrarchus labrax). Fish and Shellfish Immonology, 7, 29-43. http://dx.doi.org/10.1006/fsim.1996.0061

[10] Picchietti, S., Taddei, A.R., Scapigliati, G., Buonocore, F., Fausto, A.M., Romano, N., et al. (2004) Immunoglobulin Protein and Gene Transcripts in Ovarian Follicles throughout Oogenesis in the Teleost Dicentrarchus labrax. Cell Tissue Research, 315, 259-270. http://dx.doi.org/10.1007/s00441-003-0819-9

[11] Olsen, Y.A. and Press, C.M. (1997) Degradation Kinetics of Immunoglobulin in the Egg, Alevin and Fry of Atlantic Salmon, Salmo salar L., and the Localisation of Immunoglobulin in the Egg. Fish \& Shellfish Immunology, 7, 81-91. http://dx.doi.org/10.1006/fsim.1996.0064

[12] Magnadottir, B., Lange, S., Steinarsson, A. and Gudmundsdottir, S. (2004) The Ontogenic Development of Innate Immune Parameters of Cod (Gadus morhua L.). Comparative Biochemistry and Physiology Part B: Biochemistry and Molecular Biology, 139, 217-224. http://dx.doi.org/10.1016/j.cbpc.2004.07.009

[13] Yousif, A.N., Albright, L. and Evelyn, T.P.T. (1991) Occurrence of Lysozyme in the Eggs of Coho Salmon Oncorhynchus kisutch. Diseases of Aquatic Organisms, 10, 45-49. http://dx.doi.org/10.3354/dao010045

[14] Yousif, A.N., Albright, L.J. and Evelyn, T.P.T. (1994) In Vitro Evidence for the Antibacterial Role of Lysozyme in Salmonid Eggs. Diseases of Aquatic Organisms, 19, 15-19. http://dx.doi.org/10.3354/dao019015

[15] Swain, P. and Nayak, S.K. (2009) Role of Maternally Derived Immunity in Fish. Fish \& Shellfish Immunology, 27, 89-99. http://dx.doi.org/10.1016/j.fsi.2009.04.008

[16] Harris, J. and Bird, D.J. (2000) Modulation of the Fish Immune System by Hormones. Veterinary Immunology and Immunopathology, 77, 163-176. http://dx.doi.org/10.1016/S0165-2427(00)00235-X

[17] Milla, S., Depiereus, S. and Kestemont, P. (2011) The Effects of Estrogenic and Androgenic Endocrine Disruptors on the Immune System of Fish: A Review. Ectoxicology, 20, 305-319. http://dx.doi.org/10.1007/s10646-010-0588-7

[18] Hou, Y.Y. (1998) Endocrinological Aspects of Reduced Immunocompetence with Gonadal Maturation in Rainbow trout. Ph.D. Thesis, The University of Tokyo, Tokyo.

[19] Slater, C.H. and Schreck, C.B. (1993) Testosterone Alters the Immune Response of Chinook Salmon, Oncorhynchus tshawytscha. General and Comparative Endocrinology, 89, 291-298. http://dx.doi.org/10.1006/gcen.1993.1035 
[20] Suzuki, Y., Otaka, T., Sato, S., Hou, Y.Y. and Aida, K. (1997) Reproduction Related Immunoglobulin Changes in Rainbow Trout. Fish Physiology and Biochemistry, 17, 415-421. http://dx.doi.org/10.1023/A:1007795827112

[21] Thilagam, H., Gopalakrishnan, S., Bo, J. and Wang, K.J. (2009) Effect of 17 $\beta$-Estradiol on the Immunocompetence of Japanese Sea Bass (Lateolabrax japonicus). Environmental Toxicology and Chemistry, 28, 1722-1731. http://dx.doi.org/10.1897/08-642.1

[22] Smith, L.E. (1999) Aromatase Inhibitors: A Dose-Response Effect? Endocrine-Related Cancer, 6, 245-249. http://dx.doi.org/10.1677/erc.0.0060245

[23] Akbary, P., Mirvaghefi, A.R., Akhlaghi, M. and Majazi Amiri, B. (2015) Effect of Letrozole, Aromatase Inhibitor, on Serum Sex Steroid Levels, Egg Diameter, Gonado-Somatic Index (GSI) in Rainbow Trout (Oncorhynchus mykiss). Iranian Journal of Fisheries Science, in press.

[24] Shilling, A.D., Carlson, B. and Williams, D.E. (1999) Rainbow Trout, Oncorhynchus mykiss, as a Model for Aromatase Inhibition. The Journal of Steroid Biochemistry and Molecular Biology, 70, 89-95. http://dx.doi.org/10.1016/S0960-0760(99)00090-4

[25] Sharifiyazdi, H., Akhlaghi, M., Tabatabaei, M. and Mostafavi Zadeh, S.M. (2010) Isolation and Characterization of Lactococcus garvieae from Diseased Rainbow Trout (Oncorhynchus mykiss, Walbaum) Cultured in Iran. Iranian Journal of Veterinary Researches, 11, 342-350.

[26] Toranzo, A.E., Devesa, S., Romalde, J.L., Lamas, J., Riaza, A., Leiro, J. and Barja, J.L.M. (1995) Efficacy of Intraperitoneal and Immersion Vaccination against Enterococcus sp. Infection in Turbot. Aquaculture, 134, 17-27. http://dx.doi.org/10.1016/0044-8486(95)00038-4

[27] Romalde, J.L., Alvarez, A.L., Ravelo, C., Toranzo, A.E. and Mendez, J.B. (2004) Oral Immunisation Using Alginate Microparticles as a Useful Strategy for Booster Vaccination against Fish Lactoccocosis. Aquaculture, 236, 119-129. http://dx.doi.org/10.1016/j.aquaculture.2004.02.028

[28] Ellis, A.E. (1990) Lysozyme Assays. In: Stolen, J.S., Fletcher, T.C., Anderson, D.P., Roberson, B.S. and Van Muiswinkel, W.B., Eds., Techniques in Fish Immunology Fair Haven, SOS Publications, Fair Haven, 101-103.

[29] Swain, P., Nayak, S., Sahu, A., Mahapatra, B.C. and Meher, P.K. (2002) Bath Immunisation of Spawn, Fry and Fingerlings of Indian Major Carps Using a Particulate Antigen. Fish \& Shellfish Immunology, 13, 133-140. http://dx.doi.org/10.1006/fsim.2001.0388

[30] Sugita, H., Okano, R., Suzuki, Y., Iwai, D., Mizukami, M., Akiyama, N., et al. (2002) Antibacterial Abilities of Intestinal Bacteria from Larvae and Juvenile Japanese Flounder against Fish Pathogens. Fisheries Science, 68, $1004-1011$. http://dx.doi.org/10.1046/j.1444-2906.2002.00525.x

[31] Swain, P., Dash, S., Bal, J., Routray, P., Sahoo, P.K., Sahoo, S.K., Saurabh, S., Gupta, S.D. and Meher, P.K. (2006) Passive Transfer of Maternal Antibodies and Their Existence in Eggs, Larvae and Fry of Indian Major Carp, Labeo rohita(Han). Fish \& Shellfish Immunology, 20, 519-527. http://dx.doi.org/10.1016/j.fsi.2005.06.011

[32] Hosseini, M.H., Akhlaghi, M. and Moazzeni Jula, G. (2011) Experimental Vaccine against Lactococcosis in Cultured Rainbow Trout (Oncorhynchus mykiss). Archives of Razi Institute, 66, 51-57.

[33] Kim, J.H., Go, J., Cho, C.R., Kim, J.I., Lee, M.S. and Parka, S.C. (2013) First Report of Human Acute Acalculous Cholecystitis Caused by the Fish Pathogen Lactococcus garvieae. Journal of Clinical Microbiolgy, 51, 712-714. http://dx.doi.org/10.1128/JCM.02369-12

[34] Hou, Y., Suzuki, Y.Y. and Aida, K. (1999) Effects of Steroid Hormones on Immunoglobulin M (IgM) in Rainbow Trout, Oncorhynchus mykiss. Fish Physiology and Biochemistry, 20, 155-162. http://dx.doi.org/10.1023/A:1007799617597

[35] Cuasco, B., Gucco, M., Malacarne, G., Ottonelli, R. and Tanvez, A. (2008) Yolk Testosterone Levels and Dietary Carotenoids Influence Growth and Immunity of Grey Partridge Chicks. General and Comparative Endocrinology, 156, 418-425. http://dx.doi.org/10.1016/j.ygcen.2007.12.010

[36] Ángeles Esteban, M., Cuesta, A., Chaves-Pozo, E. and Meseguer, J. (2013) Influence of Melatonin on the Immune System of Fish: A Review. International Journal of Molecular Science, 14, 7979-7999. http://dx.doi.org/10.3390/ijms14047979

[37] Lei, L., Zhang, S., Tongo, Z. and Liu, J. (2010) In Vivo Effect of 17- $\beta$-Estradiol on Plasma Immunoglobulin Levels and Leukocyte Density in Zebrafish Danio rerio. Chinese Journal of Oceanology and Limnology, 28, 527-532. http://dx.doi.org/10.1007/s00343-009-9048-8

[38] Williams, T.D., Amer, M.D., George, S.G., Sabine, V. and Chipman, J.K. (2007) Gene Expression Responses of European Flounder (Platichtys flesus) to 17- $\beta$ Estradiol. Toxicology Letters, 168, 236-248. http://dx.doi.org/10.1016/j.toxlet.2006.10.020

[39] Wang, K.J., Cai, J.J., Qu, H.D., Yang, M. and Zhan, M. (2009) Cloning and Expression of a Hepcidin Gene from a Marine Fish (Pseudosciaena crocea) and the Antimicrobial Activity of Its Synthetic Peptide. Peptides, 30, 638-646. 
http://dx.doi.org/10.1016/j.peptides.2008.12.014

[40] Sin, Y.M., Ling, K.H. and Lam, T.J. (1994) Passive Transfer of Protective Immunity against Ichthophthiriasis from Vaccinated Mother to Fry in Tilapias, Oreochromis aureus. Aquaculture, 120, 229-237. http://dx.doi.org/10.1016/0044-8486(94)90081-7

[41] Chantanachookhin, C., Seikai, T. and Tanaka, M. (1991) Comparative Study of the Ontogeny of the Lymphoid Organs in Three Species of Marine Fish. Aquaculture, 99, 143-155. http://dx.doi.org/10.1016/0044-8486(91)90294-H

[42] Mor, A. and Avtalion, R.R. (1988) Evidence of Transfer of Immunity From Mother to Eggs in Tilapias. The Israeli Journal of Aquaculture, 40, 22-28.

[43] Mor, A. and Avtalion, R.R. (1990) Transfer of Antibody Activity from Immunized Mother to Embryo in Tilapias. Journal of Fish Biology, 37, 249-255. http://dx.doi.org/10.1111/j.1095-8649.1990.tb05856.x

[44] Takemura, A. and Takano, K. (1997) Transfer of Maternally-Derived Immunoglobulin (IgM) to Larvae in Tilapia, Oreochromis mossambicus. Fish \& Shellfish Immunology, 7, 355-363. http://dx.doi.org/10.1006/fsim.1997.0090

[45] Kanlis, G., Suzuki, Y., Tauchi, M., Numata, T., Shirojo, Y. and Kawano, K. (1995) Immunoglobulin Concentration and Specific Antibody Activity in Oocytes and Eggs of Immunized Red Sea Bream. Fisheries Science, 61, 791-795. http://www.affrc.go.jp/en/

[46] Hanif, A., Bakopoulos, V., Leonardos, I. and Dimitriadis, G.J. (2005) The Effect of Sea Bream (Sparus aurata) Broodstock and Larval Vaccination on the Susceptibility by Photobacterium damsela subsp. piscicida and on the Humoral Immune Parameters. Fish \& Shellfish Immunology, 19, 345-361. http://dx.doi.org/10.1016/j.fsi.2004.12.009

[47] Picchietti, S., Scapigliati, G., Fanelli, M. and Barbato, F., Canese, S., Mastrolia, L, et al. (2001) Sex-Related Variations of Serum Immunoglobulins during Reproduction in Gilthead Sea Bream and Evidence for a Transfer from the FEMALE to the Eggs. Journal of Fish Biology, 59, 1503-1511. http://dx.doi.org/10.1111/j.1095-8649.2001.tb00215.x

[48] Lillehaug, A., Sevatdal, G. and Endal, T. (1996) Passive Transfer of Specific Maternal Immunity Does Not Protect Atlantic Salmon (Salmo salarL.) Fry against Yersiniosis. Fish \& Shellfish Immunology, 6, 521-535. http://dx.doi.org/10.1006/fsim.1996.0049

[49] Scapigliati, G., Romano, N. and Abelli, L. (1999) Monoclonal Antibodies in Fish Immunology: Identification, Ontogeny and Activity of T- and B-lymphocytes. Aquaculture, 172, 3-28. http://dx.doi.org/10.1016/S0044-8486(98)00440-2

[50] Pepin, J.F., Brueil, G., Rigobert, P. and Romestand, B. (1997) Detection and Characterization of Immunoglobulins in the Eggs of the Sea Bass (Dicentrarchus labrax). Ichtyophysiolgy Acta, 20, 77-85.

[51] Takemura, A. (1993) Changes in an Immunoglobulin M (IgM)-Like Protein during Larval Stages in Tilapia, Oreochromis mossambicus. Aquaculture, 115, 233-241. http://dx.doi.org/10.1016/0044-8486(93)90139-P

[52] Campbell, B., Dickey, J.T. and Swanson, P. (2003) Endocrine Changes during Onset of Puberty in Male Spring Chinook Salmon, Oncorhynchus tshawytscha. Biology of Reproduction, 69, 2109-2117. http://dx.doi.org/10.1095/biolreprod.103.020560

[53] Nagae, M., Fuda, H., Hara, A., Kawamura, H. and Yamauchi, K. (1993) Changes in Serum Immunoglobulin M (IgM) Concentrations during Early Development of Chum Salmon (Oncorhynchus keta) as Determined by Sensitive ELISA Technique. Comparative Biochemistry and Physiology Part A: Physiology, 106, 69-74. http://dx.doi.org/10.1016/0300-9629(93)90041-2 
Scientific Research Publishing (SCIRP) is one of the largest Open Access journal publishers. It is currently publishing more than 200 open access, online, peer-reviewed journals covering a wide range of academic disciplines. SCIRP serves the worldwide academic communities and contributes to the progress and application of science with its publication.

Other selected journals from SCIRP are listed as below. Submit your manuscript to us via either submit@scirp.org or Online Submission Portal.
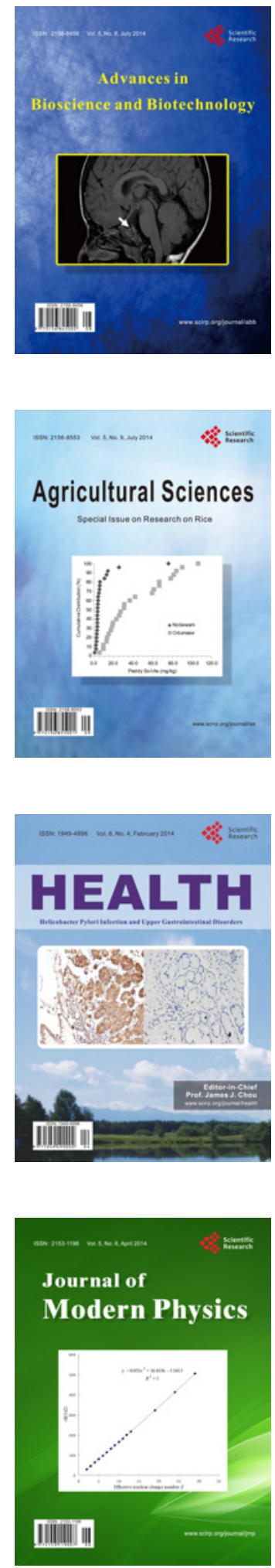
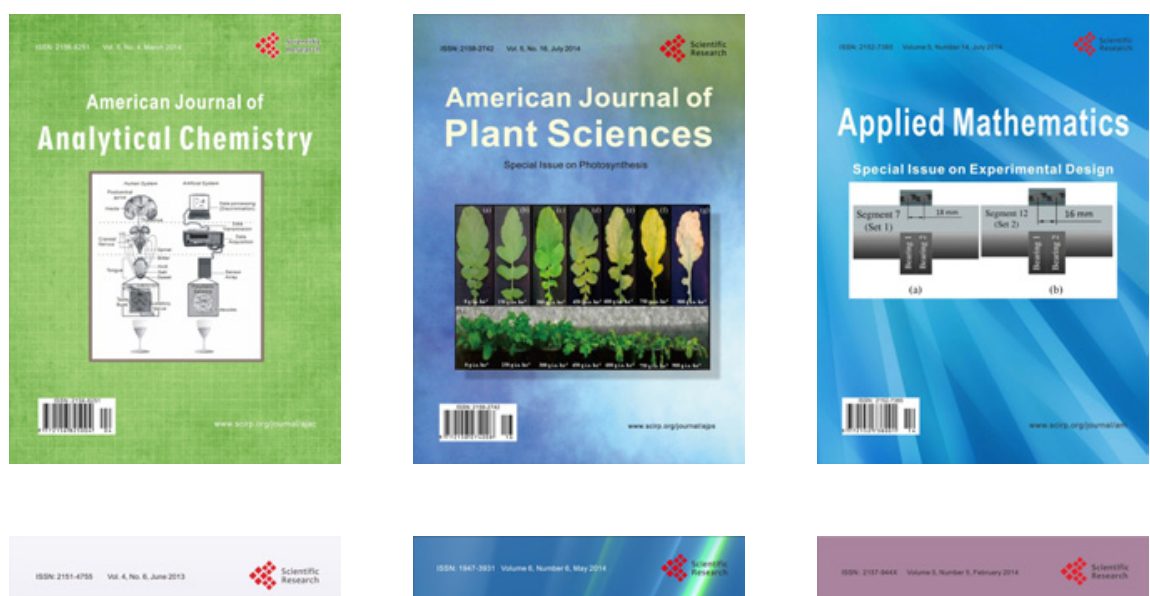

Creative Education
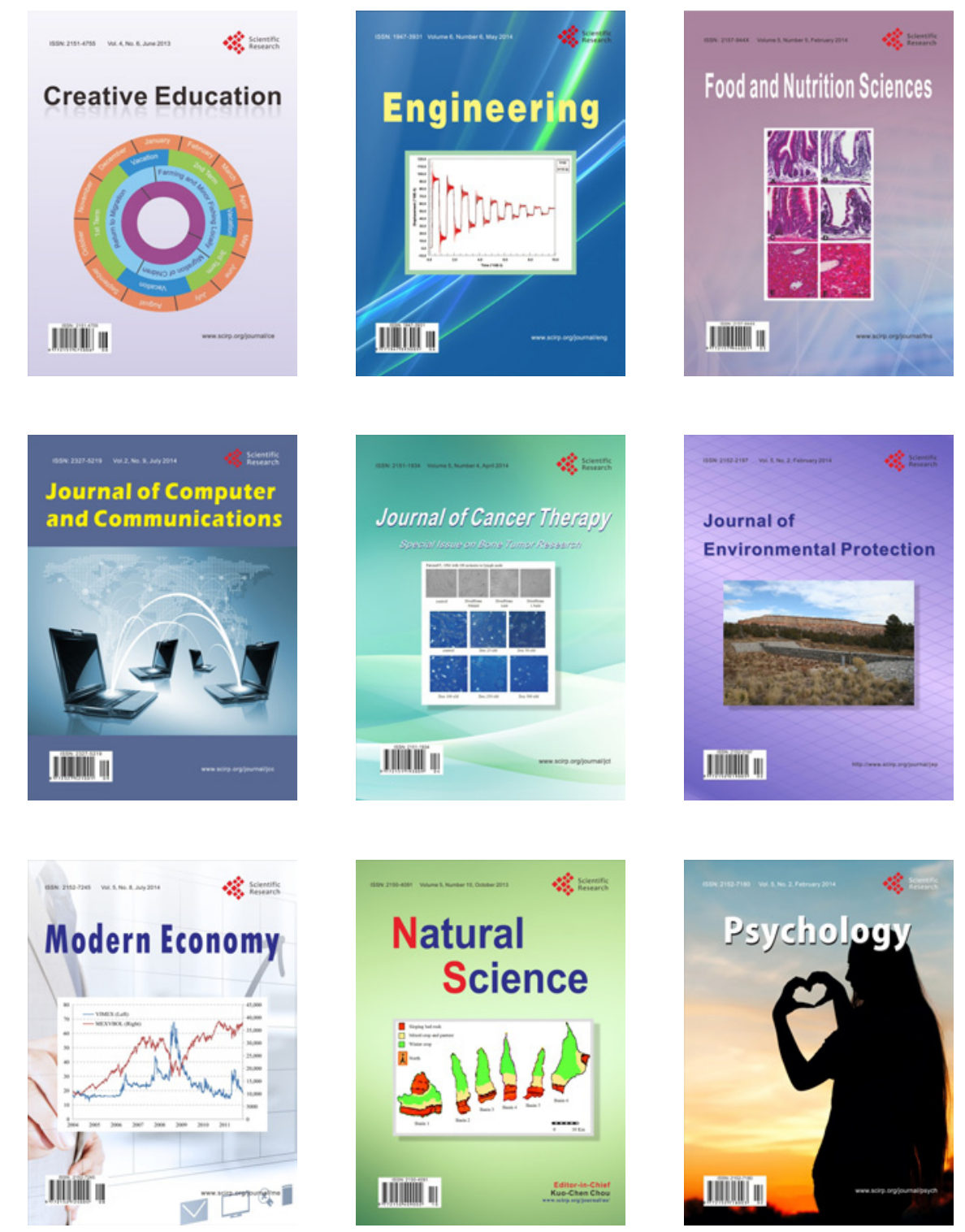